University of Nebraska - Lincoln

DigitalCommons@University of Nebraska - Lincoln

8-1986

\title{
Moving Under, Around, and Through the Miocene Reconstruction of Southern California
}

John Barron

USGS

Follow this and additional works at: https://digitalcommons.unl.edu/usgsstaffpub

Part of the Earth Sciences Commons

Barron, John, "Moving Under, Around, and Through the Miocene Reconstruction of Southern California" (1986). USGS Staff -- Published Research. 261.

https://digitalcommons.unl.edu/usgsstaffpub/261

This Article is brought to you for free and open access by the US Geological Survey at DigitalCommons@University of Nebraska - Lincoln. It has been accepted for inclusion in USGS Staff -- Published Research by an authorized administrator of DigitalCommons@University of Nebraska - Lincoln. 


\section{Moving Under, Around, and Through the Miocene Reconstruction of Southern California}

\author{
JOHN A. BARRON \\ U.S. Geological Survey \\ Menlo Park, CA 94025
}

Modern southern California is fragmented by faults that juxtapose blocks with contrasting topographies and differing geologic histories. Many of the tectonic events that have shaped southern California were initiated during the Miocene, as subduction along the ancient trench margin off southern California was replaced by transform (strikeslip) faulting, such as that along the San Andreas fault.

Miocene reconstruction of southern California was the subject of a Penrose Conference held in Oxnard, California, May 30-June 4. Sixty-four geologists, geophysicists, and paleontologists from academia, industry, and the government were brought together by $\mathrm{A}$. Eugene Fritsche (California State University, Northridge) to discuss and debate the Miocene geologic history of southern California, south of $36^{\circ} \mathrm{N}$.

A key event used in reconstructing southern California's geologic history was the arrival of the ancestral East Pacific Rise at the trench margin off western North America. The model of Atwater (1970) suggests that this event occurred in the late Oligocene $(28 \mathrm{Ma})$ at a latitude near or slightly south of Los Angeles $\left(34^{\circ} \mathrm{N}\right)$. A progressive shift of the convergent plate regime to one of right-lateral shear then followed, as the spreading center was split into two segments, one of which migrated to the north, the other to the south. During the last 12 years various modifications of the Atwater (1970) model have been invoked by researchers such as Crowell (1974), Blake et al. (1978), Dickinson and Snyder (1979), and Crouch (1979) to explain basin formation, the cessation of volcanism, and the initiation of strikeslip faulting in different regions of central and southern California.

As if the Miocene tectonic history of southern California were not compli- cated enough, the Transverse Ranges, a large segment of southern California trending east from Santa Barbara through northern Los Angeles to the Mojave Desert, apparently have been rotated clockwise by as much as $90^{\circ}$ since the early middle Miocene, as a result of dextral shear between the North American and Pacific plates (Luyendyk et al., 1980, 1985).

Furthermore, it seems that major strike-slip faulting in southern California has moved progressively inshore with time. The San Gabriel fault, west of the San Andreas fault, first became a major strike-slip surface in the late middle Miocene (11-12 Ma), while transform faulting was not initiated on the modern-

\section{The modelers turned to the few paleontologists in attendance and asked to know accurate ages, paleobathymetry, and paleolatitudes.}

day trace of the San Andreas fault in southern California until the latest Miocene (5-6 Ma).

Alternative models were presented at the conference that challenged the timing and sequence of these various events. For example, Stan Keith (MagnaChem, Inc., Phoenix, AZ) presented geochemical evidence on volcanic rocks from throughout the southwestern United States that suggested to him that subduction off the southern California coast did not begin to wane until near the end of the early Miocene (17 Ma). Steve Lund (University of Southern California) argued that paleomagnetic data indicate that the rocks of the Santa Monica Mountains were as much as $15^{\circ}$ farther south during most of the Miocene, an assertion challenged by Bruce Luyendyk (University of California, Santa Barbara).
Consideration of tectonic models and their effect on the Miocene paleogeography of southern California clearly requires a regional study with accurate dating of depositional, magmatic, and structural events. Consequently, the Penrose participants were split into seven groups, corresponding in general to the seven main geographic provinces of southern California: the Coast Ranges, the Transverse Ranges, the Continental Borderland, the Los Angeles basin, the San Joaquin Valley, the Mojave Desert, and the Colorado Desert. These working groups spent the first day of the conference drawing detailed geologic columns of key Miocene sections in their respective areas. It was hoped that area-to-area comparison of these columns would provide constraints on the various reconstructions. For example, were the ages of the volcanics rocks the same in different areas? How did sections of deepsea fan sediment compare from area to area and was their distribution supportive of the tectonic displacements predicted by the various tectonic models?

Certain similarities in the geologic columns did emerge such as a regionwide cessation of most volcanism at about 12-10 Ma. However, the geologic complexity of the Miocene of southern California also was made clearly evident, and participants began to discover some of the limitations to making detailed reconstructions for the area. At this point, the modelers turned to the few paleontologists in attendance and asked to know accurate ages and the paleobathymetric and paleolatitudinal histories of various formations.

In some sections and some areas the information the modelers sought was available. For example, I showed that marine diatoms allow age resolution approaching $300,000 \mathrm{yrs}$. in the middle and upper Miocene Monterey Formation. Judy Smith (Consultant, Palo Alto, CA) presented refined Pecten lineages that allow improved biostratigraphy of the upper Oligocene and lower Miocene Vaqueros Formation. Martin Lagoe (University of Texas, Austin) summarized the value of benthic foraminifers for paleobathymetry and their limitations in constructing chronologies.

However, the number of paleontologists who are now actively publishing on 
the Miocene of southern California is far exceeded by the geologists and geophysicists actively working on the area. This disparity reflects both the decline in numbers of paleontologists on the faculties of almost every West Coast geology department and the tendency of active paleontologists to pursue study in the more glamorous fields of paleobiology and paleoceanography. Much of the published material on biostratig-

\section{Much of the published material is more than $\mathbf{3 0}$ years old, so paleontology has an enormous potential for testing these models.}

raphy and paleoecology of the Miocene of southern California is more than 30 years old and does not consider recent advances and methods in paleontology. Clearly, the few active paleontologists in this field cannot hope to answer the numerous questions raised by the various models of the Miocene tectonic history of California. Yet I believe paleontology has an enormous potential (Barron, 1986) for the testing and application of these models. Recent studies of pa- leomagnetic stratigraphy and strontiumisotope dating in the area show great promise for refining existing biochronologies. Similarly, continued elucidation of the Miocene paleoceanographic and paleoclimatologic history of the area and of the North Pacific as a whole will allow improved interpretation of the Miocene paleogeography of southern California.

Such an effort, however, need not be a one-way street of aid to our geologist and geophysicist colleagues. Paleontologists can answer fundamental questions of taxon evolution, paleogeography, and paleoecology in addressing such questions. At the same time, we should convince our geologist and geophysicist colleagues that paleontologists can offer a valuable resource and that they should consider adding a "modeler" to their faculty who uses fossils as his tool.

All in all, I found the Penrose Conference on the Miocene reconstruction of southern California to be a rewarding experience that demonstrated again how much geoscientists can learn from each other when they cooperate in the study of fundamental geologic problems.

\section{REFERENCES}

ATWATER, T., 1970, Implications of plate tectonics for the Cenozoic tectonic evolution of western North America: Geological Society of America Bulletin, v. 81, p. 3513-3535.

Barron, J. A., 1986, Paleoceanographic and tectonic controls on deposition of the Monterey Formation and related siliceous rocks in California: Palaeogeography, Palaeoclimatology, Palaeoecology, v. 53, p. 27-45.

Blake, M. C., JR., Campbell, R. H., Dibblee, T. W., JR., Howell, D. G., Nilsen, T. H., Normark, W. R., Vedder, J. G., and SilVER, E. A., 1978, Neogene basin formation in relation to plate-tectonic evolution of the San Andreas Fault system, California: American Association of Petroleum Geologists Bulletin, v. 62 , p. $344-374$.

Crouch, J. K., 1979, Neogene tectonic evolution of the California Continental Borderland and western Transverse Ranges: Geologic Society of America Bulletin, v. 90, p. 38-345.

Crowell, J. C., 1974, Origin of late Cenozoic basins in southern California: Special Publication, Society of Economic Paleontologists and Mineralogists, no. 22, p. 190-204.

DiCKINSON, W. R., and SNYDER, W. S., 1979, Geometry of triple junctions related to San Andreas transform: Journal of Geophysical Research, v. 84(B2), p. 561-572.

LuYendyk, B. P., Kamerling, M. J., and Ter. RES, R. R., 1980, Geometric model for Neogene crustal rotations in southern California: Geological Society of America Bulletin, v. 91, p. 211-217.

LuYendyk, B. P., Kamerling, M. J., Terres, R. R., and Hornafius, J. S., 1985, Simple shear of southern California during Neogene time suggested by Paleomagnetic declinations: Journal of Geophysical Research, v. 90 (B14), p. $12454-12466$.

\section{MIDYEAR ANNUAL MEETING}

SEPM's fourth midyear meeting will be held 11-14 August, 1987, in Austin, Texas. For information contact either SEPM Headquarters (918) 743-9765, or the General Chairman, Dr. Robert A. Morton, Bureau of Economic Geology, University of Texas, University Station, Box X, Austin, TX 78712; (512) 471-1534. More in forthcoming issues.

\section{Overheard at SEPM President's reception, Atlanta}

Larry Sloss: I don't know five people here, and I used to know every member of the Society.

Preston Cloud: You don't have to know them, they know youyou're part of the exhibits now! 